\title{
THERAPEUTIC EXPERIMENTS IN CASES OF RETINITIS PIGMENTOSA*
}

B Y

\author{
DR. IMRE BIRÓ \\ ASSISTANT AT THE UNIVERSITY EYE CLINIC, BUDAPEST
}

At the Grand Meeting of the Hungarian Ophthalmological Society held in 1934 I gave a short and cursory account, within the frame of a lecture dealing with the links between retinitis pigmentosa and the endocrine system, of those experiments which were carried on in our clinic on the field of this severe affection with sexual hormone therapy, namely with ovarian and testicular extracts respectively. ${ }^{1}$ These therapeutic experiments were initiated partly through the stimulating effect of. Wibaut's achievements and on the ground of his conception, and partly on the ground of our own observations. Wibaut, as is well known, starting from the fact that retinitis pigmentosa occurs much more frequently in men than women and that the disease presents a considerably milder form in the latter, concluded that the female genital glands exert a certain particular resisting power against retinitis pigmentosa. Wibaut administered menformon, that is an ovarian extract, to men, also to women, while our clinic employed glandubolin (folliculin) to women and testiculin injections for men. The theoretical rationale of this has already been expounded by us in a publication dealing with the causal connection between the pathological picture of retinitis pigmentosa and the sexual glands and on this occasion I only allude to that old observation of ours, that in some of our patients reaching the age of puberty, both male and female, a spontaneous transitory improvement of vision of a certain degree could be noticed. We therefore assumed that this improvement was brought about by increased metabolism and strengthening oxidative energy due to sexual glands just starting increase in function. At the same time we conceded that in all probability other, at present yet less elucidated factors, were acting. Because of these it seemed reasonable to make a trial to influence the severity of the pathological picture by the administration of glandular extracts.

In the course of the years since 1934, beside sexual hormone therapy we gathered observations also in regard to the administration of other drugs; thus two years ago we had occasion to publish a report on our experiences gained with the administration of amyl nitrite. The huge material of the University Eye Clinic

* Abstract of an address delivered to the Hungarian Ophthalmological Society on February 26, 1938.

(1) Hungarian Grand Medical Week, Vol. IV, p. 320, 1934.

(2) Gyógyászat, p. 246, April 18, 1938. 
No. 1, later that of the University Eye Clinic rendered it possible to make investigations with the application of the above methods, likewise the administration of liver extracts on other groups of patients, and thus we were in the position to observe the action of these drugs so that the patient received no other drugs besides that administered for trial. We made no experiments with other than the above mentioned three drugs, namely sexual hormones, amyl nitrite and liver extract-later on we combined these-in spite of the fact that in the literature we often find references to the action of the hypophysis, thyroid and parathyroid extracts, that is endocrine gland extracts. But we did not wish to waste our clinical material. This paper describes our experiences during the last six years.

During the period 1932 to 1938 25 patients suffering from retinitis pigmentosa were treated at the University Eye Clinic with the methods to be detailed hereafter. Most of these have been and are under our observation for years. Besides these there were under our observation further 10 patients, but these received no treatment. Thus our patients numbered 35, of whom 25 were males and 10 females. These figures in their proportion agree with foreign statistics. Out of the 25 treated patients 16 were males and 9 females.

Treatment was made according to the following distribution : 5 men received injections of testicular extract, 3 women injections of glandubolin, 1 woman received exhepar (liver) injections. Amyl nitrite inhalations were given to 13 patients - 7 males and 6 females-the latter combined with the administration of exhepar injections was given to five men as a trial to influence, even if only for a time, their declining vision. Two patients figure twice in the list, this is why 25 patients are grouped under $2 \tau$ numbers.

The observations made in regard to the hereditary conditions, to the other complications arising out of it, to the single types of the disease, and the experiences gained in connection with the treatment are described in the cases detailed below:

In the case of one out of the five males treated with testiculin injections-the patient was 28 years of age, an offspring of blood kin parents, deaf and dumb, suffering from adiposogenital dystrophy-every attempt proved futile. In two other cases-one aged 40 years, the other aged 21 years (cases 1,3 ), visual acuity did not change, while the visual field considerably widened. In the cases of two further patients, one a man aged 41 years, the other a boy aged 12 years $(2,4)$, both visual acuity, as well as the visual field and adaptation improved, that is to say increased. Visual acuity improved in the case of the previous man only subjectively, while in the case of the boy it improved from $5 / 50$ to $5 / 10$. In the second case the widening of the visual field was remarkable. 
Group I. Patients treated with testicular extract.

\begin{tabular}{|c|c|c|c|c|}
\hline No. & $\begin{array}{c}\text { Age and sex of } \\
\text { patient }\end{array}$ & before ${ }_{\text {treatr }}^{\text {Visual }}$ & $\begin{array}{l}\text { acuity } \\
\text { after }\end{array}$ & Remarks \\
\hline 1 & $\begin{array}{l}\text { K. A., male, } \\
\text { aged } 40 \text { years }\end{array}$ & $\begin{array}{l}5 / 70 ! \\
5 / 70 j\end{array}$ & Idem & $\begin{array}{l}\text { In his family the disease was inherited } \\
\text { already through four generations in a } \\
\text { dominant way. Parents are not blood } \\
\text { relations. Endocrinological test: } \\
\text { hypogenitalism of a minor degree. } \\
\text { Pigmentation found only in the } \\
\text { vicinity of the equator. Visual field : } \\
\text { See Fig. No. 1. }\end{array}$ \\
\hline 2 & $\begin{array}{l}\text { G. Gy., male, } \\
\text { aged } 41 \text { years }\end{array}$ & $\begin{array}{l}\text { Counts fingers } \\
\text { from } \frac{1}{2} \text { metres } \\
\text { c.f. from } 3 \\
\text { metres; with } \\
\text { corr. } 5 / 15 \\
5 / 10\end{array}$ & $\begin{array}{l}\text { Idem, subjec- } \\
\text { tively improved }\end{array}$ & $\begin{array}{l}\text { Cousin of the above. His father } \\
\text { suffered from this same disease. } \\
\text { Endocrinology: genital hypoplasia } \\
\text { of a minor degree. Vision subjec- } \\
\text { tively improved after the hormone } \\
\text { treatment in } 1934 \text {. In } 1936 \text { improved } \\
\text { to } 5 / 7 \text { upon amyl nitrite inhalations. } \\
\text { In both eyes posterior polar cataract. }\end{array}$ \\
\hline 3 & $\begin{array}{l}\text { Sz. J., male, } \\
\text { aged } 21 \text { years }\end{array}$ & $\begin{array}{l}\text { c.f. } \frac{1}{2} \mathrm{~m} . \\
5 / 70\end{array}$ & Idem & $\begin{array}{l}\text { Parents: no blood relations, no family } \\
\text { history. Endocrinology: hypogeni- } \\
\text { talism, infantile constitution, no } \\
\text { other pathological change. Subse- } \\
\text { quent to treatment with testiculin, } \\
\text { after half a year interval, amyl nitrite } \\
\text { inhalations. In the right eye the } \\
\text { process extends also to the region of } \\
\text { the macula. Visual field: see Fig. } 2 .\end{array}$ \\
\hline 4 & $\begin{array}{l}\mathrm{Cz} . \mathrm{M} ., \text { male, } \\
\text { aged } 12 \text { years }\end{array}$ & $\begin{array}{l}5 / 50 \\
5 / 50\end{array}$ & $\begin{array}{l}5 / 10 \\
5 / 10\end{array}$ & $\begin{array}{l}\text { Parents no blood relations. There is no } \\
\text { family predisposition. Endocrinology: } \\
\text { genital hypoplasia, otherwise normal } \\
\text { conditions. Fundus, retinitis pig- } \\
\text { menta sine pigmento. }\end{array}$ \\
\hline 5 & $\begin{array}{l}\text { H. B., male, } \\
\text { aged } 30 \text { years }\end{array}$ & $\begin{array}{l}\text { c.f. } 1 / 2 \mathrm{~m} . \\
\text { c.f. } 1 / 2 \mathrm{~m} .\end{array}$ & Idem & $\begin{array}{l}\text { Blood relationship between parents. } \\
\text { Patient imbecile, deaf and dumb, } \\
\text { suffers from dystrophia adiposo- } \\
\text { genitalis (Biedl-Moon). Posterior } \\
\text { cortical cataract. Heavily pig- } \\
\text { mented fundus. No thorough } \\
\text { examination was feasible. }\end{array}$ \\
\hline
\end{tabular}

Group II. Patients treated with glandubolin injections.

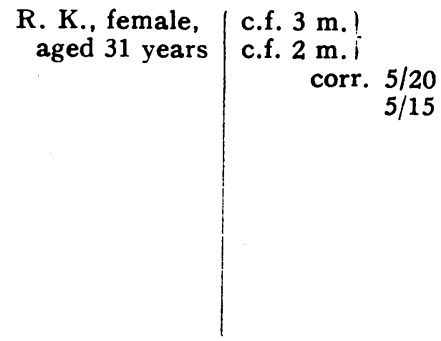
Idem, subjec-
tively improved
Her family and hereditary history could not be revealed. The patient is deaf and dumb and does not remember her parents, or her relatives. Endocrinology : increased metabolism (+27 per cent.) besides a sympatheticotonic blood sugar curve there was no pathological change whatever. Cranial skiagram : the normal size of the sella is at its minimum. Visual field: slightly widened at the centre. 
Group II. Patients treated with glandubolin injections-continued.

\begin{tabular}{|c|c|c|c|c|}
\hline \multirow{2}{*}{$\begin{array}{r}\text { No. } \\
7\end{array}$} & \multirow{2}{*}{$\begin{array}{l}\text { Age and sex of } \\
\text { patient } \\
\text { A. E., female, } \\
\text { aged } 20 \text { years }\end{array}$} & \multicolumn{2}{|c|}{ before $\left.\right|_{\text {treatment }} ^{\text {Visual acuity }}$ after } & Remarks \\
\hline & & $\begin{array}{l}5 / 30 \\
5 / 30\end{array}$ & Idem & $\begin{array}{l}\text { Parents are distant blood relations. } \\
\text { Impaired hearing. Endocrinology: } \\
\text { slightly exaggerated basal metabo- } \\
\text { lism, otherwise normal conditions. } \\
\text { The considerably constricted visual } \\
\text { field is not changed. (After a glandu- } \\
\text { bolin cure amyl nitrite inhalations } \\
\text { were of no avail.) Cortical cataracts } \\
\text { in both eyes. }\end{array}$ \\
\hline 8 & $\begin{array}{r}\mathrm{Cz} . \mathrm{K} . \text {, female, } \\
\text { aged } 28 \text { years }\end{array}$ & $\begin{array}{l}5 / 70 \\
5 / 70\end{array}$ & $\begin{array}{l}5 / 30 \\
5 / 30\end{array}$ & $\begin{array}{l}\text { Family and hereditary history normal } \\
\text { through three generations. Fun- } \\
\text { dus: initial stage, only slightly } \\
\text { constricted blood vessels, few gran- } \\
\text { ules, visual field improved. }\end{array}$ \\
\hline
\end{tabular}

Group III. Patients treated with liver extracts.

Idem Normal familial and hereditary his-
tory. Circular pigmentation can
be noticed only about the region of
the equator in the fundus. The blood
vessels relatively normal. Visual
field, loss was noticeable only be-
tween $30^{\circ}$ and $40^{\circ}$ It disappeared
upon 12 exhepar injections. There
was no change in vision.

\section{Group IV. Patients treated with amyl nitrite inhalations.}

H. O., male, aged 33 years

c.f. from $2 \mathrm{~m}$. c.f. from $1 \mathrm{~m}$.

H. L., male, aged 28 years

R. I., female, aged 30 years

c.f. $3 \mathrm{~m}$.

c.f. $3 \mathrm{~m}$.

-corr. 5/10
Idem

Idem

Idem
Two brothers. Parents are no blood relations. They know nothing about other members of their family and their grandparents. Both are deaf and dumb. The sight of the elder deteriorated after a long spontaneous improvement in 1932. The visual field which was constricted up to $5^{\circ}$ was uninfluenced. The deterioration of vision, the constricted visual field did not change in the younger brother either. The endocrinological examination established late puberty, decreased basal metabolism. They refused to be treated with hormone injections. In both cases very severe and progressed eyeground processes, atrophy of optic nerves, filiform blood vessels were observed. Posterior cortical cataract.

Negative familial and hereditary history. Impaired hearing. A relatively milder eyeground process. No improvement either in the visuat field or in the visual acuity. 
GrouP IV. Patients treated with amyl nitrite inhalations-continued.

\begin{tabular}{|c|c|c|c|c|}
\hline No. & $\begin{array}{c}\text { Age and sex of } \\
\text { patient }\end{array}$ & \multicolumn{2}{|c|}{ before $\left.\right|_{\text {treatment }} ^{\text {Visual acuity }}$ after } & Remarks \\
\hline 13 & $\begin{array}{l}\text { M. Gy., } \\
\text { aged } 60 \text { years }\end{array}$ & $\begin{array}{l}5 / 10 \\
5 / 10\end{array}$ & Idem & $\begin{array}{l}\text { Parents blood relations. One of his } \\
\text { uncles is suffering from a simila } \\
\text { disease. Too much pigment, very } \\
\text { thinned blood vessels on the eye } \\
\text { ground. Posterior cortical cataract } \\
\text { The visual field slightly widened } \\
\text { after the administration of } 15 \text { inhal } \\
\text { ations (see Fig. 3), the improvemen } \\
\text { of vision was only subjective. }\end{array}$ \\
\hline 14 & $\begin{array}{l}\text { B. E., female, } \\
\text { aged } 22 \text { years }\end{array}$ & $\begin{array}{l}\text { c.f. } 1 / 2 \mathrm{~m} . \\
\text { c.f. } 1 / 2 \mathrm{~m} .\end{array}$ & Idem & $\begin{array}{l}\text { Two sisters. A biotker of theirs, who } \\
\text { received no treatment is in a similar } \\
\text { serious condition. In both a rudi } \\
\text { mentary sixth digit on the hands } \\
\text { and feet. In the fundus: a very } \\
\text { advanced process, atrophic discs } \\
\text { very narrow blood vessels. }\end{array}$ \\
\hline 15 & $\begin{array}{l}\text { B. R., female, } \\
\text { aged } 25 \text { years }\end{array}$ & $\begin{array}{l}\text { Hand move- } \\
\text { ments }\end{array}$ & Idem & $\begin{array}{l}\text { In several instances inhalation treat } \\
\text { ment was employed which failed to } \\
\text { bring about any improvement in } \\
\text { vision, eyeground or adaptation. }\end{array}$ \\
\hline 16 & $\begin{array}{l}\text { G. Gy., male, } \\
\text { aged } 41 \text { years, } \\
\text { occurs also } \\
\text { sub. No. } 1 \\
\text {. }\end{array}$ & $\begin{array}{l}\text { c.f. } \frac{1}{2} \mathrm{~m} . \\
\begin{array}{l}\frac{\mathrm{corr} .}{} 5 / 15 \\
\text { c.f. } 3 \mathrm{~m} . \\
- \text { corr. } 5 / 15\end{array}\end{array}$ & $\begin{cases} & 5 / 7 \\
\text { corr. } & 5 / 7\end{cases}$ & $\begin{array}{l}\text { Sufficiently considerable visual field } \\
\text { widening besides subjectively im- } \\
\text { proved visual acuity, following the } \\
\text { administration of testiculin injec- } \\
\text { tions. The patient came again } \\
\text { for testing after two years; vision } \\
\text { was worse, visual field further con- } \\
\text { stricted. Upon the administration of } \\
20 \text { amyl nitrite inhalations the visual } \\
\text { field widened just as after treat- } \\
\text { ment with hormones. Visual acuity } \\
\text { improved. (See Fig. 4.) }\end{array}$ \\
\hline
\end{tabular}

17 T. B., male, +14.0 O.D. 5.30 corr. 5/15 aged 49 years +12:0 O.D. $5 / 70$ (aphakic) corr. 5/15

18

M. K., female, -corr. 5/12 aged 52 years - corr. $5 / 12$

19

B. K., male, aged 27 years

I. J., male, aged 24 years c.f. $2 \mathrm{~m}$.

c.f. $2 \mathrm{~m}$.
- corr. $5 / 8$

- corr. $5 / 8$.

c.f. $1 \mathrm{~m}$.

$5 / 70$

$5 / 70$

Idem

Some years ago intracapsular cataract operation was performed on both eyes. Familial and hereditary history negative. The fundus picture pointed to a milder process. Visual field widened.

Normal familial and hereditary conditions. Milder, fundus process. (See Fig. 5.)

In his family the affection was dominantly inherited through three generations. Parents are no blood relations. Visual field: slight improvement.

Parents are blood relations. Impaired hearing. Severe fundus picture. Cortical cataract. Considerably constricted visual field. Condition after 17 inhalations unchanged. 
Retinitis Pigmentosa

GROUP IV. Patients treated with amyl nitrite inhalations-continued.

\begin{tabular}{|c|c|c|c|c|}
\hline No. & $\begin{array}{c}\text { Age and sex of } \\
\text { patient }\end{array}$ & \multicolumn{2}{|c|}{ before $\left.\right|_{\text {treatment }} ^{\text {Visual acuity }}$ after } & Remarks \\
\hline 21 & $\begin{array}{l}\text { S. F., female, } \\
\text { aged } 23 \text { years }\end{array}$ & $\begin{array}{l}5 / 50 \\
5 / 50\end{array}$ & Idem & $\begin{array}{l}\text { Her maternal grandmother is suffering } \\
\text { from similar eye disease. Parents no } \\
\text { blood relations. Visual field made } \\
\text { no change. }\end{array}$ \\
\hline 22 & $\begin{array}{l}\text { R. K., female, } \\
\text { aged } 31 \text { years. } \\
\text { occurs also } \\
\text { sub. } 6\end{array}$ & $\begin{array}{l}\text { c.f. } 3 \mathrm{~m} . \\
\text { - } \mathrm{corr} .5 / 20 \\
\text { c.f. } 2 \mathrm{~m} . \\
- \text { corr. } 5 / 15\end{array}$ & Idem & $\begin{array}{l}\text { Upon the administration of glandu- } \\
\text { bolin injection in 1933-35 vision sub- } \\
\text { jectively improved, the visual field } \\
\text { widened a little at the centre. Half } \\
\text { a year later even this little result } \\
\text { faded away. In } 1937 \text { some improve- } \\
\text { ment was achieved with hormone } \\
\text { treatment; similar improvement was } \\
\text { achieved also with amyl nitrite treat- } \\
\text { ment. }\end{array}$ \\
\hline
\end{tabular}

Group V. Amyl nitrite and exhepar injections.

H. I., male,

O. J., male,

H. K., male aged 27 years aged 37 years aged 39 years

$5 / 12$

$5 / 70$

$5 / 30$

$5 / 60$

$5 / 70$ aged 38 years
$5 / 30$

c.f. $1 \mathrm{~m}$.
Idem

$5 / 20$

$5 / 30$

Idem

Normal familial and hereditary history. Posterior polar cataract. The concentrically strongly constricted visual field displayed no change after treatment.

Normal familial and hereditary conditions. Endocrinological and internal reports negative. Cortical cataract. Visual field widened. (See Fig. 6.)

In his family there are several members suffering from similar eye troubles. His parents are no blood relations. Endocrinological, -internal-and neurological reports negative. Visual field widened. (See Fig. 7.)

Parents no blood relations. Has no notion about the occurrence of similar eye affections in his family. Impaired hearing. Internal-and endocrinological reports negative. The concentrically strongly constricted visual field was unchanged.

In his family there are several similar patients. Internal-and endocrinological reports negative. Visual field on both sides constricted up to $10^{\circ}$. After receiving 10 inhalations and 10 exhepar injections the patient did not present himself any more and so the tests could not be completed. 

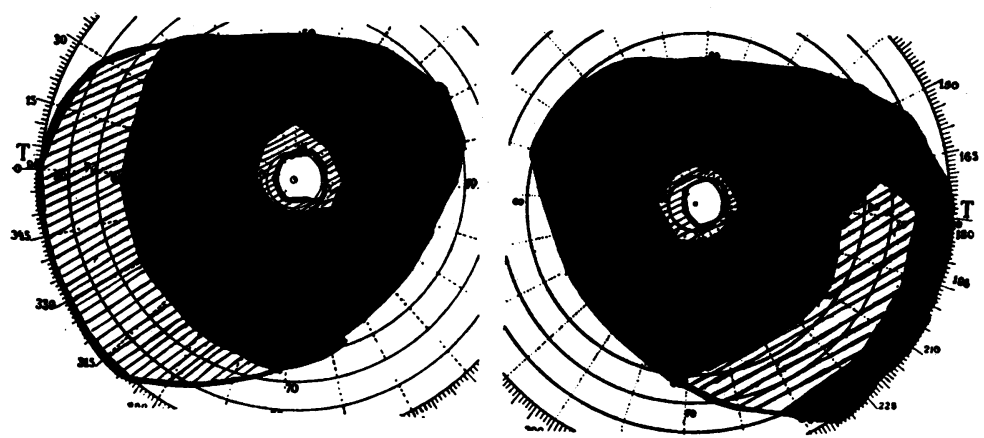

FIG. 1.
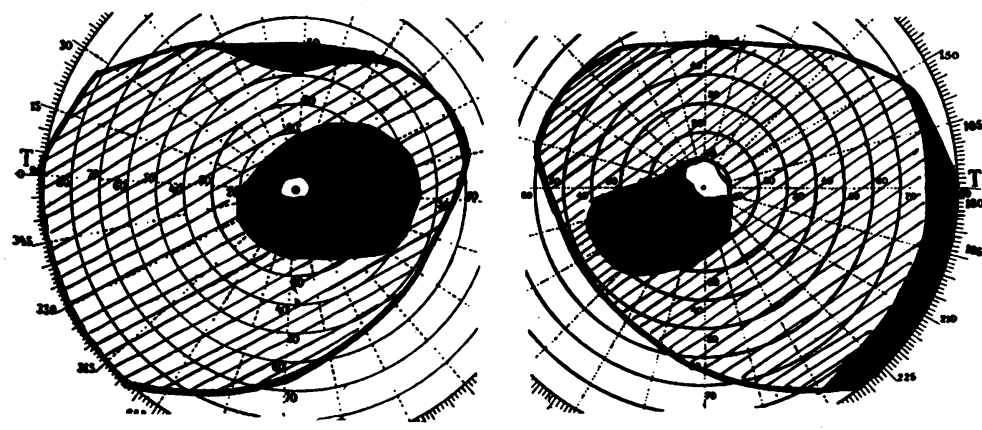

FIG. 2.
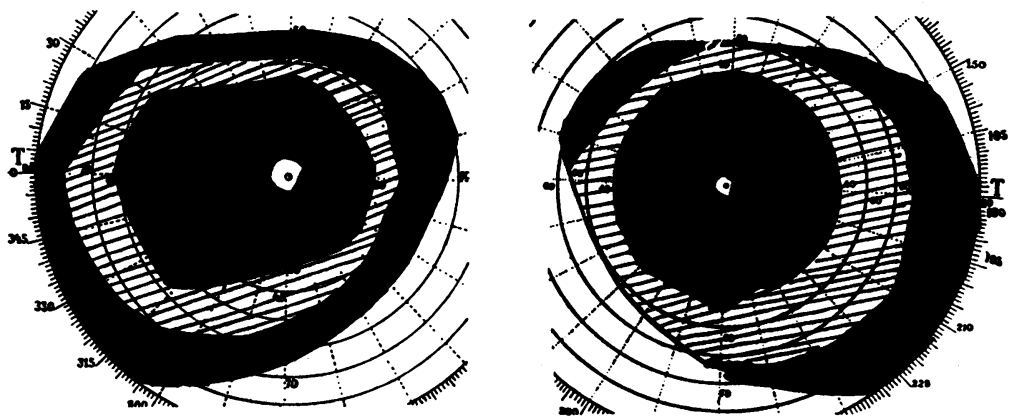

Area cleared up as a result of treatment.

FIG. 3. 

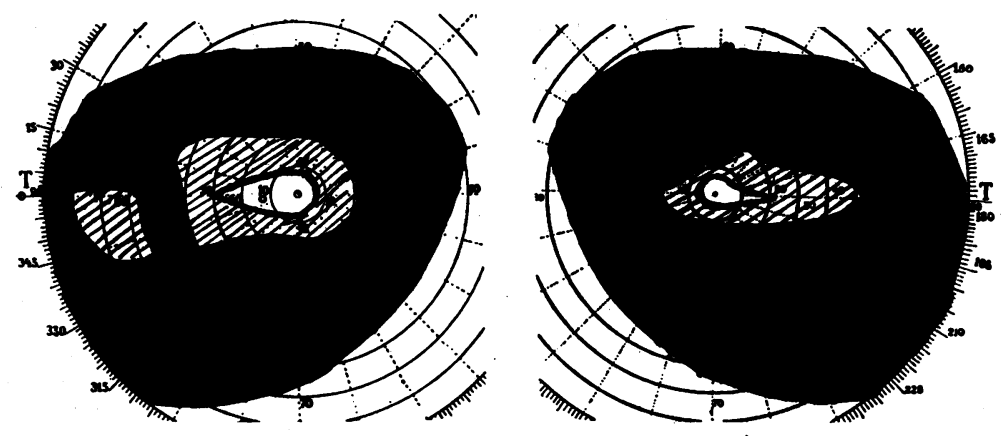

FIG. 4.
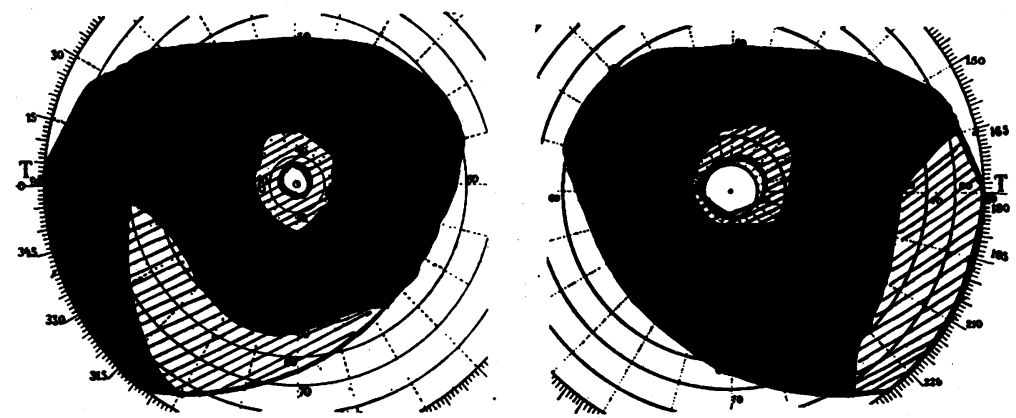

Fig. 5.
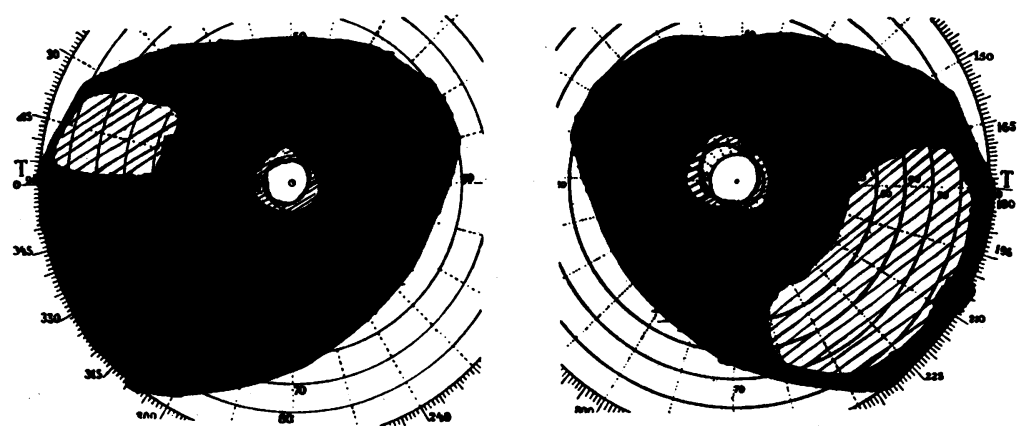

FIG. 6.

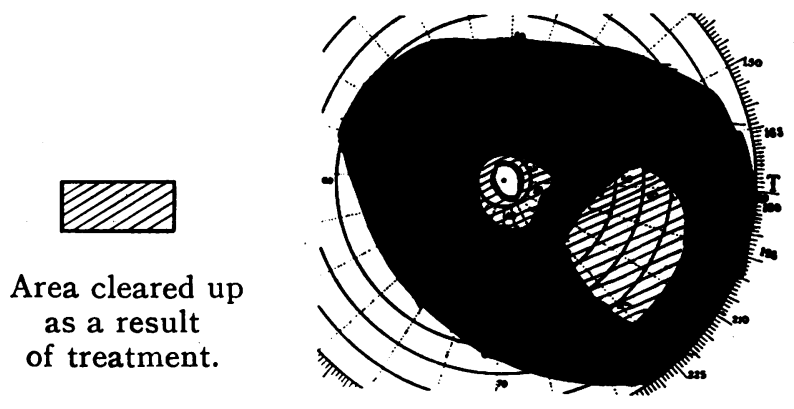

Fig. 7. 
The importance of these few cases is the fact that it seems to shake Wibaut's assumption, according to which the female hormones are possessed of certain singular resisting power against the factors making the patients ill, while the male hormones are not possessed of this property. If this were so, then every trial with testiculin would have proved futile. Therefore, predominance of males with retinitis pigmentosa cannot be explained exclusively by the protecting rôle of the ovaries, because according to all probability the origin of retinitis pigmentosa is directed by pathological factors-independent of sexes-of intra-uterine development. In fact, sexual hormone therapy is reasonable and purposeful only where endocrinological and neurological tests bear out the existence of hypogenitalism, or late puberty, that is to say weakened influence of genital gland-function which checks and delays normal living processes. In the course of our investigations, besides the conception of Wibaut and our own observations, the results of the endocrinological tests instigated us to utilise the old employed and proved efficient drugs against this disease.

We administered glandubolin-as well after very thorough preliminary examinations-in three female patients. The first two $(6,7)$, sprung from the marriage of blood relations, one of them deaf and dumb, the other partially deaf, in these we failed to achieve any improvement. Two years after the unsuccessful treatment with glandubolin the deaf and dumb patient was given amyl nitrite inhalations with which we attained a slight alleviation, which was too unimportant to be evaluated from a scientific point of view. The third patient (8), a woman, genetically as well as constitutionally healthier than the former, finished her cure with a vision improved from $5 / 70$ to $5 / 30$, and with a much widened visual field. This last patient's treatment and tests were made by Dr. Stephen de Grósz, clinical assistant.

One female has been treated with liver extract only. Starting from the observation that in patients suffering from hepatic diseases changes in the fundus similar to retinitis pigmentosa have often been noticed, and on the other hand liver is the most efficacious medicine for hemeralopia incident to retinitis pigmentosa, the systematic application of liver preparations has been long since introduced into the therapy of retinitis pigmentosa. The researches made in latter years corroborate and strongly accentuate the importance of the rôle of liver beside the endocrine glands to which the liver stands at any rate very near. The rôle of the liver in regard to the metabolism of the retina, in the building up of the visual purple is indisputable. Favourable results were achieved with it particularly by American authors.

Our 9 th case was a female, aged 26 years, who presented herself 
in the initial stage of the disease, visual acuity corrected to $5 / 7$, with a scarcely $5-6^{\circ}$, circular, ring scotoma corresponding to the site of the equator.

Examining the patient after 15 exhepar injections the ringshaped scotoma was no longer demonstrable, the visual field became wholly free. The vision was unaltered.

We gave an account of our experiments with amyl nitrite inhalations two years ago (3). We accentuated at that time that amyl nitrite in cases of fundus disease thus also in retinitis pigmentosa is absolutely not an aetiologic, but a symptomatical drug, which influences the constriction of the arteries, the primary consequence of the cause and not the cause of the disease. If, however, we consider that that unknown and primary causal factor which provoked the narrowing of the arteries impairs the blood supply of the retina also on account of the spasm caused by itself-which naturally of course promotes the decline of vision-then we have to admit that the vasodilating amyl nitrite by reducing ischaemia is capable of weakening one of the most severe attacking points of the disease and thereby, indirectly, also the action of the primary causal factor.

In the above-mentioned treatise, in which I dealt with the technique of amyl nitrite inhalations, its effect upon the vascular system and also with examinations made with the tonoscillograph, I published data also about eight individuals suffering from retinitis pigmentosa, treated only with amyl nitrite, every one of whom was under my control for at least half a year subsequent to the treatment. The number of my patients treated with amyl nitrite rose to 13 ( 6 males, 6 females), with five new patients who were also under my care for a longer period. Out of the 13 patients 5 ( 4 males, 1 female) improved both in visual acuity and visual field, 8 were not improved ( 3 males, 5 females).

Combined amyl nitrite and exhepar treatment was given to 5 men, in 2 of which cases the visual acuity and visual field respectively improved, while in the remaining 3 patients I failed to attain satisfactory results.

Conclusion :-I succeeded in attaining more or less improved results with testicular extract in 4 out of 5 , with ovarian extract in 1 out of 3 , with amyl nitrite inhalation in 5 out of 13 , with amyl nitrite combined with liver extract in 2 out of 5 , that is to say out of $2 \tau$ treated cases there was improvement in 13 instances. Patient No. 27 disappeared prior to the completion of the examinations and so the above final results are confined only to 26 patients.

As I have mentioned several times in other publications (4),

(3) Klin. Monatsbl.f. Augenheilk., Vol. XCVI, p. 490, 1936.

(4) Arch. d'Ophtal., T. 53, No. 9, 1936. 
in a case of retinitis pigmentosa the type of heredity is of decisive importance as to the condition and function of the eye, and to a certain extent it determines the severe or less severe character of the disease. According to the observation of our clinic retinitis pigmentosa inherited in a dominant way presents a milder form and can be much more influenced, than the form of disease inherited by a recessive route. Out of 35 treated and untreated cases of ours we failed to mitigate the symptoms in a single case inherited in a dominant manner. In 9 cases the process of heredity was of a recessive character.

Five patients originated from the marriage of blood relations. There were amongst the patients 6 deaf and dumbs, two partially deaf, 2 polydactylic and 2 suffering from adiposo-genital dystrophy. Cortical (posterior) cataract has been observed in 11, glaucoma in 1 instance. It was striking how frequent was myopic astigmatism. The Wassermann test gave negative reports in all the treated cases.

Surveying the results we see, that besides the unchanged condition, or a very slight improvement of the visual acuity - the slow decline of which can be reduced to the deeper and more central process-the widening of the visual field is the more significant. All those substances, with which we experimented, directly or indirectly raised the blood supply of the retina, also its oxidative processes, metabolism, and if only in a slight extent and though transiently, they at any rate restored certain already out-lying areas into normal function of the retina. These "cleared up" areas, as can be seen in the figures, became displaced chiefly from the equator toward the ora serrata, that is peripherally, further from the equator towards the centre (that is the periphery clears up a little and the concentric constriction widens), which elucidatorily proves the double advance of the gravest degeneration towards the equator, and the possibility of stopping this advance for a short time.

From the circumstance that with all the above enumerated drugs we succeeded in obtaining improvement of identical character, we may draw the conclusion that neither of these drugs is a specific therapy for retinitis pigmentosa, as the true therapy, the much accentuated " tuning " of the organism, its endocrine, neurogenic and thus constitutional transformation is yet beyond our knowledge. But any one of the methods either the dilating of the arteries, or the raising and stimulating of the metabolism, oxidation therefore the nutrition of the retina is capable of improving in some instances and even then to a slight extent. Not so much that it were apt to arouse hopes, but at least in such a measure that it would be a mistake to pass over it indifferently. 